\title{
PENGARUH MEDIA SOSIAL DAN TEMAN SEBAYA TERHADAP PERILAKU KONSUMTIF MAHASISWA
}

\author{
Kadeni $^{1)}$ Ninik Srijani ${ }^{2)}$ \\ STKIP PGRI Blitar ${ }^{1)}$ Universitas PGRI Madiun ${ }^{2)}$ \\ denikdk@gmail.com ${ }^{1)}$ ninikikipae@gmail.com ${ }^{2)}$
}

\begin{abstract}
The purpose of this study are: 1) to determine the influence of social media on student consumptive behavior; 2) to know the influence of peers against student consumptive behavior; 3) to know the influence of social media and peers against the behavior of consumer consumptive STKIP PGRI Blitar. Type of correlational research with a sample of 95. Data collection techniques using questionnaires and documentation. Data analysis techniques use multiple linear regression. The results showed 1) there is a social media influence on student consumptive behavior; 2) there is influence of association of peer to student consumptive behavior and 3) there is influence of social media and peer to student's consumptive behavior.
\end{abstract}

Keywords: Social Media, Peers, Consumptive Behavior

\begin{abstract}
Abstrak
Tujuan penelitian ini adalah: 1) untuk mengetahui pengaruh media sosial terhadap perilaku konsumtif mahasiswa; 2) untuk mengetahui pengaruh teman sebaya terhadap perilaku konsumtif mahasiswa; 3) untuk mengetahui pengaruh media sosial dan teman sebaya terhadap perilaku konsumtif mahasiswa STKIP PGRI Blitar. Jenis penelitian korelasional dengan sampel sejumlah 95. Teknik pengumpulan data menggunakan angket dan dokumentasi.Teknik analisis data menggunakan regresi linear berganda. Hasil penelitian menunjukkan1) ada pengaruh media sosial terhadap perilaku konsumtif mahasiswa; 2) ada pengaruh pergaulan teman sebaya terhadap perilaku konsumtif mahasiswa dan 3) ada pengaruh media sosial dan teman sebaya terhadap perilaku konsumtifmahasiswa.
\end{abstract}

Kata kunci: Media Sosial, Teman Sebaya, Perilaku Konsumtif 


\section{PENDAHULUAN}

Saat ini perkembangan dan kemajuan teknologi dan sangat pesat sudah masuk dalam sendi-sindi kehidupan yang tidak bisa dihindarkan. Media sosial sebagai salah satu dari perkembangan teknologi dan informasi sangat pesat sekali. Dalam berkomunikasi hampir semua kalangan masyarakat sudah menggunakan alat teknologi untuk mengakses informasi melalui internet. Internet (kependekan dari interconnectionnetworking) adalah seluruh jaringan komputer yang saling terhubung menggunakan standar sistem global Transmission Control Protocol/Internet Protocol Suite (TCP/IP) sebagai protokol pertukaran paket (packet switching communication protocol) untuk melayani miliaran pengguna internet di seluruh dunia. Rangkaian internet yang terbesar inilah yang dinamakan Internet. Cara menghubungkan rangkaian dengan kaidah ini dinamakan internetworking ("antarjaringan").

https://id.wikipedia.org/wiki/Internet. Jenis pelayanan internet yang sangat popular atau terkenal yaitu bisa untuk digunakan sebagai sarana media sosial. Media sosial adalah sebuah media dalam jaringan (daring), dengan para penggunanya bisa dengan mudah berpartisipasi, berbagi, dan menciptakan isi meliputi jejaring sosial, forum, wiki, dunia virtual dan blog. Jejaring sosial, blog, dan wiki adalah bentuk media sosial yang umumnya paling banyak dipergunakan oleh masyarakat di seluruh dunia dalam memanfaatkan media sosial.https://id.wikipedia.org/wiki/Media.S aat ini beberapa jenis media sosial yang banyak dipergunakan adalah twitter, blackberry messenger, facebook, yahoo messenger, kakao talk, whatsapp, line, wechat dan e-mail dan lain-lain.

Bila di kaitkan dengan perubahan pola perilaku konsumtif bagi penggunanya, pemanfaatan dan penggunaan media sosial dapat menimbulkan dampak positif maupun negatif. Perilaku negatif dari penggunaan media sosial diantaranya: a. jika sudah daringorang sering lupa dengan waktu dan menghabiskan pulsa, b. orang mudah terhasut dengan pembicaraan orang lain yang menjurus pada penghinaan terhadap seseorang sehingga menimbulkan SARA. c. pengguna akan mudah tertarik dengan berbagai promosi dan kemudahan dalam berbelanja secara daring dan menimbulkan perilaku konsumtif.

Di samping itu pergaulan dengan teman sebaya juga sangat mempengaruhi perubahan perilaku seseorang dalam memenuhi kebutuhannya. Menurut Sentrock (2007) menyatakan bahwa teman sebaya merupakan kelompok yang terdiri dari anakanak atau remaja yang memiliki usia atau tingkat kematangan yang hampir sama. Dengan demikian teman sebaya adalah sekelompok individu yang mempunyai hubungan pada anak-anak atau remaja dengan tingkat usia yang relative sama dan melibatkan keakraban yang relatif besar. Pentingnya dari kelompok teman sebaya adalah di dalamnya merupakan tempat mereka untuk memberikan informasi tentang dunia luar keluarga yang sangat diperlukan untuk perkembangan dan kematangan individu. Melalui aktivitas pada kelompok teman sebaya mereka akan menerima umpan balik dari temantemannyatentang kemampuannya, masingmasing anggota kelompokakan memberikan penilaiandari yang mereka lakukan berakibat baik atau buruk.Apakah yang di lakukan lebih baik dari pada temantemannya sama ataukah lebih buruk dari teman-teman lain kerjakan. Pengaruh pergaulan dari kelompok teman sebaya ini bersifat eksternal. Bila tidak mempunyai dorongan internal, minat, bakat atau 
kemampuan yang dibutuhkan untuk menyelesaikan suatu tugas, maka kemungkinan besar remaja akan mengalami kegagalan. Dengan demikian pengaruh dari pergaulan teman sebaya maka jelas tampak sekali bila penggunaan alat teknologi dan informasi sangat mempengaruhi perubahan perilaku seseorang di dalam kehidupan sehari-hari utamanya dalam perilaku memenuhi kebutuhannya atau konsumtif.

\section{Media Sosial}

Media sosial atau dalam bahasa Inggris "social media" menurut tata bahasa terdiri dari kata "social" yang memiliki arti kemasyarakatan atau sebuah interaksi, dan " media" adalah sebuah wadah atau tempat sosial itu sendiri (www.id.wikipedia.org/ wiki/facebook/). Media sosial merupakan sebuah media dalam jaringan dengan para penggunanya yang bisa dengan mudah berpartisipasi, berbagi, dan menciptakan isi seperti jejaring sosial, blog, dan wiki adalah bentuk media sosial yang umumnya paling banyak dipergunakan oleh masyarakat di seluruh dunia dalam memanfaatkan media sosial.

Menurut Kaplan media sosial sebagai sebuah kelompok aplikasi berbasis internet yang membangun di atas dasar ideology dan tekhnologi web 2.0 dan yang memungkinkan penciptaan dan pertukaran "user generated content" (https://id.wikipedia.org/ wiki/Media).

Seiring dengan perkembangan zaman dan berkembangnya teknologi informasi dan komunikasi, maka banyak sekali bermunculan media yang bisa membantu memudahkan orang untuk dapat mengakses berbagai macam hal salah satunya adalah media sosial. Mulai dari internet sampai jejaring sosial, bahkan sekarang ini media sosial dapat di akses melalui handphone dengan tampilan-tampilan baru dan menarik bagi penggunanya. Pengguna jejaring sosial penggunannya juga sudah sampai ke daerahdaerah pelosok dengan menggunakan bantuan tower yang disediakan oleh pihak provider.

Itu membuktikan bahwa orang sudah mengetahui betapa bermanfaatnya media sosial ini untuk melakukan pertukaran data dan informasi secara luas kepada orang banyak. Mereka juga semakin sadar bahwa media sosial mempunyai banyak manfaat di berbagai hal dalam bidang kebudayaan, perekonomian, kepariwisataan, kesehatan dan bidang-bidang lainnya. Manfaat dari media sosial yaitu: a. Pesan yang disampaikan tidak hanya untuk satu orang saja, namun bisa ke berbagai banyak orang. b. Pesan yang disampaikan cenderung lebih cepat di banding menggunakan media yang lainnya. c. Pesan yang disampaikan bebas.

Saat ini penggunaan media sosial sudah beragam jenisnya mulai dari facebook, blackberry messenger, whatsapp, yahoo, twitter, line, wechat, kakao talk, instagram. Jenis-jenis media sosial yang adayaitu: a. Proyek kolaborasi sama dengan website mengijinkan penggunanya untuk dapat mengubah, menambah, ataupun menghapus konten-konten yang ada di website ini. b. Blog sama dengan pengguna lebih bebas dalam mengekspresikan sesuatu blog ini seperti curhat ataupun mengkritik kebijakan pemerintah. c. Konten adalah para pengguna dari pengguna website ini saling mengshare konten-konten media baik seperti video, foto, gambar dan lain-lain. d. Situs jejaring sosial yaitu aplikasi yang mengijinkan pengguna untuk dapat terhubung dengan cara membuat informasi pribadi sehingga dapat terhubung dengan orang lain. e. Virtual game world adalah dimana mengreplikasikan lingkungan 3D dan dimana pengguna bisa muncul dalam bentuk avatar-avatar yang diinginkan serta 
berinteraksi dengan orang lain selayaknya di dunia nyata. f. Virtual social world yang dimana penggunanya merasa hidup di dunia virtual sama seperti virtual game world berinteraksi dengan dengan orang lain.

Media sosial memiliki beragam aplikasi bawaan yang fungsinya bisa dikatakan sebagai one stop service. Dengan aplikasi ini, beberapa aktivitas online secara 'multitasking' seperti berkirim pesan, chatting, bloging, dan sebagainya dapat dilakukan oleh pemilik akun. Dengan aplikasi ini, pengguna bisa menampilkan beberapa fasilitas yang ada di media sosial (Hidayat, 2014), yaitu: a. Menampilkan foto atau gambar-gambar dalam jumlah yang banyak, foto tersebut sebaiknya dikelompokkan dalam beberapa kategori dengan membuat album. b. Mengunggah video dari komputer atau perangkat mobile, merekam video dengan webcam, melihat tayangan video dan menyimpan video. c. Notes adalah aplikasi bagi pengguna media sosial yang senang menulis dengan jumlah karakter yang relative banyak layaknya bloging. d. Groups adalah aplikasi yang dapat digunakan untuk membuat kelompok.

\section{Teman Sebaya}

Teman sebaya adalah merupakan hubungan individu pada anak-anak atau remaja yang memiliki usia atau tingkat kematangan yang kurang lebih sama, Sentrock (2007). Teman sebaya merupakan kumpulan dari beberapa individu untuk memperoleh informasi yang tidak didapat di dalam keluarga, tempat menambah kemampuan dan tempat kedua setelah keluarga yang mengarahkan dirinya menuju perilaku yang baik serta memberikan masukan terhadap kekurangan yang dimilikinya.

Pada awalnya kelompok teman sebaya aktivitasnya adalah bermain diluar rumah dan bergaul dengan temanya lebih luas dalam lingkungan sosial. Pergaulan mereka semakin meluas dan terbentuklah suatu kelompok yang disebut teman sebaya sebagai tempat penyesuaian diri yang diperoleh dari luar lingkungan rumah. Di dalam kelompok teman sebaya akan timbul persahabatan yang merupakan ciri khas tertentu dan bersifat interaksi dalam pergaulan. Kesatuan dari persahabatan itu dapat disebut kelompok, jika telah memenuhi beberapa persyaratan yang ditentukan. Anggota dari kelompok sebaya itu terdiri dari sejumlah individu yang mempunyai tingkat usia dan status yang hampir sama. Istilah dalam kelompok sebaya tersebut dapat menunjukkan kelompok anak-anak, kelompok remaja dan kelompok orang dewasa.

Di dalam kelompok sebaya individu akan belajar bergaul dengan sesamanya dan mereka akan belajar memberi dan menerima dengan sesama temannya. Partisipasi anggota di dalam kelompok sebaya akan memberikan kesempatan yang besar bagi individu mengalami proses belajar sosial. Aktivitas pergaulan yang dilakukan dengan teman sebaya merupakan sesuatu yang penting untuk persiapan kehidupan mereka setelah dewasa kelak. Kebebasan dalam kelompok sebaya bisa artikan sebagai kebebasan untuk berpendapat, mengeluarkan idenya, bertindak atau untuk menemukan identitas dirinya masingmasing. Karena dalam kelompok, anggota yang lain juga mempunyai tujuan dan keinginan yang sama terhadap dengan teman sebayanya.

Bahwa terdapat jenis-jenis kelompok teman sebaya menurut Andi (1982) jenisjenis tersebut adalah: a. Kelompok chums (sahabat karib) yaitu kelompok dimana remaja bersahabat karib dengan ikatan dan persahabatan yang sangat kuat. Kelompok ini biasanya anggotanya terdiri dari 2-3 
orang dengan memiliki minat yang sama dan jenis kelamin yang sama, kemampuan dan kemauan yang mirip. Beberapa kemiripan itulah yang membuat antar anggotanya sangat akrab, meskipun kadangkadang terjadi perselisihan, tetapi dengan mudah mereka melupakan, seperti teman sebaya. b. Cliques (kelompok sahabat) biasanya terdiri dari 4-5 yang memiliki minat, kemampuan dan kemauan yang relatife sama. Cliques biasanya terdiri dari penyatuan dua sahabat karib atau dua chums. Jenis kelamin pada cliques umumnya sama, dalam cliques ini pada mulanya banyak melakukan kegiatan bersama, menonton bersama, rekreasi, pesta, saling menelepon. c. Crowds (kelompok banyak remaja) yaitu kelompok yang biasanya terdiri dari banyak remaja, lebih besar dari dibandingkan dengan cliques. Karena besarnya kelompok, maka jarak emosi antar anggota juga agak renggang. Terdapat jenis kelamin berbeda serta terpada keragaman kemampuan, minat diantara anggota. Kesamaan mereka adalah adalah bahwa mereka mempunyai perasaan takut diabaikan atau tidak diterima oleh anggota lain dalam kelompoknya. d. Gangs merupakan kelompok yang terbentuk dengan sendirinya pada umumnya merupakan akibat pelarian dari beberpa kelompok yang disebutkan sebelumnya. Remaja biasanya kebanyakan terpengaruh kebutuhan pribadi dan sosial, mereka belajar memahami teman-teman mereka dan peraturan yang ada. Ada remaja yang gagal dalam memenuhi kebutuhan tersebut, yang disebabkan ditolak oleh teman sepergaulannya, atau tidak dapat menyesuaikan diri dalam kelompok tersebut. Anggota gangs biasnya berlainan jenis dan dapat pula sama.

Menurut Haditono (2004) hubungan persahabatan bersifat timbal balik dan memiliki sifat-sifat sebagai berikut: a. Saling pengertian, b. Saling membantu, c. Saling percaya (dapat menyimpan rahasia), d. Saling menghargai dan menerima, e. Aktivitas dan interes Bersama, f. Saling terbuka (segalanya dibicarakan bersama), g. Empati (ikut merasakan), h. Mengisi kekurangan yang lain (sahabat mempunyai sifat yang diinginkan), i. Relasi yang dekat (kelekatan satu dengan yang lain berdasarkan keterbukaan dan kehalusan rasa).

\section{Perilaku Konsumtif}

Kehidupan semua manusia akan dibatasi oleh aturan agar dapat berbuat dan berperilaku sesuai yang dianggap baik oleh masyarakat. Di manapun masyarakat berada pasti akan mengalami perubahan yang terjadi akibat adanya kegiatan interaksi antar manusia. Subadi (2009) menyatakan bahwa perubahan itu tidak dapat dihindarkan lagi dan merupakan suatu keniscayaan, dengan adanya kemajuan ilmu dan teknologi membawa banyak perubahan. Perubahan dimaksud antara lain perubahan tentang norma-norma yang berlaku, tingkah laku, nilai dan pola-pola tingkah laku manusia baik secara individu maupun kelompok.

Menurut teori tindakan dikatakan bahwa sikap mempengaruhi perilaku melalui suatu proses pengambilan keputusan yang teliti dan beralasan dan dampaknya hanya pada tiga hal, yaitu: 1 . Perilaku tidak banyak ditentukan oleh sikap umum tetapi ditentukan oleh sikap spesifik (rasionalitas) terhadap sesuatu. 2. Perilaku tidak hanya dipengaruhi oleh sikap, tetapi juga oleh norma-norma subyektif yaitu keyakinan mengenai apa yang orang lain inginkan. 3. Sikap terhadap suatu perilaku bersamasama norma subyektif membentuk suatu niat untuk berperilaku tertentu. Secara sederhana teori ini mengatakan bahwa seseorang akan melakukan suatu perbuatan (perilaku) 
apabila ia memandang perbuatan itu positif dan bila ia percaya bahwa orang lain ingin agar ia melakukannya. Terkait dengan perilaku konsumtif Suminar dan Meiyuntari (2013) mendefinisikan bahwa perilaku konsumtif merupakan perilaku mengkonsumsi barang dan jasa yang mahal dengan intensitas yang terus meningkat demi mendapatkan sesuatu yang lebih baru, lebih bagus dan lebih banyak serta melebihi kebutuhan yang sebenarnya untuk menunjukkan status sosial, prestige, kekayaan dan keistimewaan, juga untuk mendapatkan kepuasan akan kepemilikan.

Faktor-faktor yang mempengaruhi perilaku konsumtif seseorang dapat berasal dari internal maupun eksternal.Faktor internal terdiri dari: a. Faktor psikologis meliputi: motivasi diri yaitu berupa kecenderungan seseorang untuk berbelanja atau membeli tanpa menggunakan faktor rasionalnya; persepsi merupakan suatu pandangan dari seseorang yang baik menyebabkan orang tersebut bertindak secara rasional; pendirian dan tingkat kepercayaan seseorang dengan kepercayaan yang tinggi pada penjual dan pendirian yang tidak stabil untuk berbelanja. b. Faktor individu yang meliputi: usia, pekerjaan, keadaan ekonomi, kepribadian dan jenis kelamin.Sedangkan faktor eksternal yang mempengaruhi perilaku konsumtif adalah: a. lingkungan sosial seperti pergaulan teman sebaya, budaya setempat, kelas sosial dan keadaan keluarga.

\section{METODE PENELITIAN}

Jenis penelitian ini adalah berjenis korelatif dengan variabel media sosial, teman sebaya dan perilaku konsumtif mahasiswa yang berupa data kuantitatif. Sumber datanya adalah semua mahasiswa STKIP PGRI Blitar sebanyak 469 dengan sampel 95 mahasiswa diambil secara acak atau random.

Data dikumpulkan menggunakan teknik angket dan dokumentasi. Untuk analisis menggunana regresi linier berganda yang di olah menggunakan bantuan program SPSS versi 22.

\section{HASIL DAN PEMBAHASAN}

Hasil analisis dengan menggunakan program SPSS (StatisticalProductand Service Solution) 22 for Windows, adalah sebagai berikut:

Tabel 1

Hasil Analisis Korelasi Media Sosial dan Pergaulan Teman Sebaya Secara Parsial Terhadap Perilaku Konsumtif

Correlations

\begin{tabular}{|c|c|c|c|c|}
\hline & & $\begin{array}{l}\text { MEDIA } \\
\text { SOSIAL }\end{array}$ & $\begin{array}{r}\text { TEMAN } \\
\text { SEBAYA }\end{array}$ & PERILAKU \\
\hline MEDIA & Pearson Correlation & 1 & $264^{* *}$ & $282^{* *}$ \\
\hline \multirow[t]{2}{*}{ SOSIAL } & Sig. (2-tailed) & & .010 & .006 \\
\hline & $\mathrm{N}$ & 95 & 95 & 95 \\
\hline TEMAN & Pearson Correlation & $.264^{* *}$ & 1 & .109 \\
\hline \multirow[t]{2}{*}{ SEBAYA } & Sig. (2-tailed) & .010 & & .023 \\
\hline & $\mathrm{N}$ & 95 & 95 & 95 \\
\hline \multirow[t]{3}{*}{ PERILAKU } & Pearson Correlation & $.282^{* * *}$ & .209 & 1 \\
\hline & Sig. (2-tailed) & .006 & .009 & \\
\hline & $\mathrm{N}$ & 95 & 95 & 95 \\
\hline
\end{tabular}

**. Correlation is significant at the 0.01 level (2-tailed). 
Berdasarkan tabel 1 dapat dijelaskan sebagai berikut:

1. Ada hubungan media sosial dengan perilaku, hal ini dapat dilihat dari nilai sig. sebesar 0.006 lebih kecil dari nilai probabilitas 0.05 , artinya variabel media sosial berhubungan secara signifikan dengan perilaku konsumtif.
2. Ada hubungan teman sebaya terhadap perilaku, hal ini dapat dilihat dari nilai sig. sebesar 0.009 lebih besar dari nilai probabilitas 0.05 , artinya variabel media sosial berhubungan secara signifikan dengan perilaku konsumtif.

Tabel 2

Hasil Analisis Uji F Pengaruh Media Sosial dan Pergaulan Teman Sebaya Secara Simultan Terhadap Perilaku

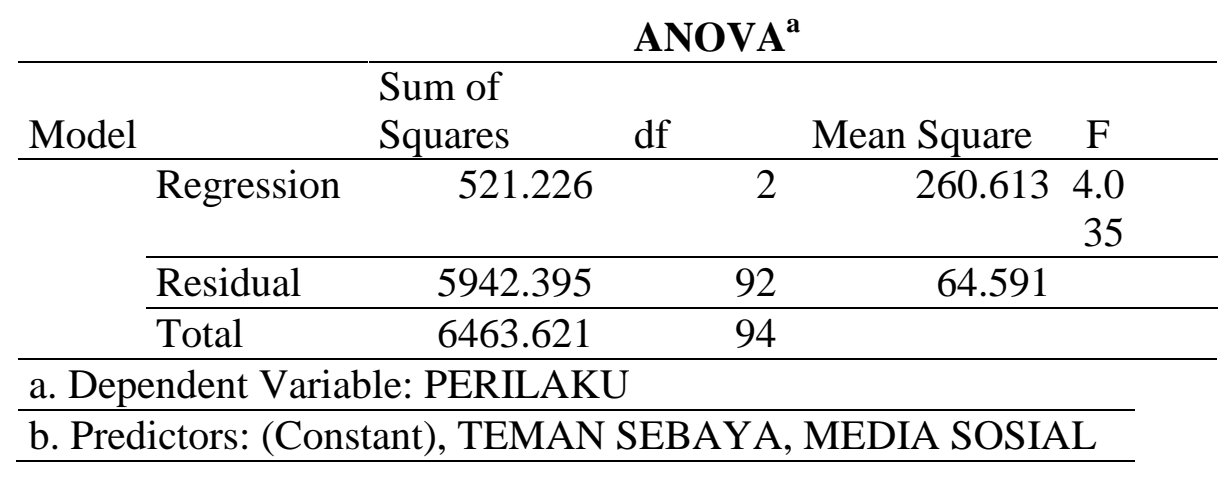

Berdasarkan table 2 dapat dikatakan bahwa secara simultan media sosial dan pergaulan teman sebaya berpengaruh terhadapperilaku konsumtif, hal ini dapat dilihat dari nilai sig. sebesar 0.021 lebih kecil dari nilai probabilitas 0.05 , artinya model regresi berganda dapat dipergunakan untuk memprediksi perilaku konsumtif.

Tabel 3

Hasil Analisis Pengaruh Media Sosial dan

Pergaulan Teman Sebaya Secara Simultan Terhadap Perilaku

Coefficients $^{\mathrm{a}}$

\begin{tabular}{|c|c|c|c|c|c|c|}
\hline \multirow{2}{*}{\multicolumn{2}{|c|}{ Model }} & \multicolumn{2}{|c|}{$\begin{array}{c}\text { Unstandardized } \\
\text { Coefficients }\end{array}$} & \multirow{2}{*}{$\begin{array}{l}\text { Standardized } \\
\text { Coefficients } \\
\text { Beta } \\
\end{array}$} & \multirow[b]{2}{*}{$\mathrm{t}$} & \multirow[b]{2}{*}{ Sig. } \\
\hline & & $\mathrm{B}$ & Std. Error & & & \\
\hline \multirow[t]{3}{*}{1} & (Constant) & 44.669 & 11.073 & & 4.034 & .000 \\
\hline & $\begin{array}{l}\text { MEDIA } \\
\text { SOSIAL }\end{array}$ & .380 & .145 & .272 & 2.623 & .010 \\
\hline & $\begin{array}{l}\text { TEMAN } \\
\text { SEBAYA }\end{array}$ & .342 & .136 & 137 & 2.361 & .019 \\
\hline
\end{tabular}

a. Dependent Variable: PERILAKU

Pengujian hipotesis berdasarkan tabel 3 dapat dijelaskan sebagai berikut:

1. Hipotesis 1 yang berbunyi ada pengaruh media sosial dengan perilaku diterima, hal ini dapat dilihat dari nilai sig. sebesar 0.010 lebih kecil dari nilai probabilitas 0.05 .

2. Hipotesis 2 yang berbunyi ada pengaruh teman sebaya terhadap perilaku diterima, 
hal ini dapat dilihat dari nilai sig. sebesar 0.019 lebih besar dari nilai probabilitas 0.05 .

3. Hipotesis 3 yang berbunyi ada pengaruh media sosial dan pergaulan teman sebaya dengan perilaku, hal ini dapat dilihat dari nilai sig. sebesar 0.000 lebih kecil dari nilai probabilitas 0.05 .

Kemajuan teknologi sudah tidak bisa dipungkiri lagi akan berpengaruh pada para penggunanya baik anak-anak, remaja dan orang tua. Seperti saat sekarang ini, kemajuan teknologi utamanya internet utamanya penggunaan media sosial sudah masuk ke sendi-sendi kehidupan mereka dalam hal ini para mahasiswa. Apapun yang terjadi di dunia luar sudah tidak bisa terhalang oleh waktu dan tempat. Hal demikian ini pasti akan berdampak terhadap perilaku seseorang dalam melakukan belanja untuk memenuhi kebutuhannya secara daring. Sesuai dengan hasil penelitian ini terbukti bahwa penggunaan media sosial berpengaruh terhadap perilaku konsumtif karena nilai sig. sebesar 0.010 lebih kecil dari nilai probabilitas 0.05. Perilaku dimaksud dapat berupa perilaku yang positif maupun yang negatif. Sehingga setiap individu harus menyadari bahwa apa yang mereka ketahui di media sosial belum tentu baik untuk perkembangan perilakunya. Seperti diketahui bahwa sekarang ini di media sosial ditawarkan berbagai maacam produk dengan berbagai fasilitas kemudahan, harga yang menarik dan kemudahan dalam mendapatkannya tanpa harus keluar rumah. Media sosial yang terus berkembang ini yang diprediksi mampu mempengaruhi perilaku konsumtif mahasiswa dalam memenuhi semua kebutuhannya.

Selain itu perilaku seseorang juga dipengaruhi oleh kelompok teman sebayanya yang akan memberikan kesempatan yang besar bagi seseorang mengalami proses belajar sosial. Bergaul dengan teman sebaya merupakan persiapan penting bagi kehidupan setelah dewasa. Di dalam dunia kerja, dalam kehidupan keluarga, dan dalam kegiatan rekreasi orang harus bergaul dengan orang-orang lain yang sebaya (Ahmadi, 2004). Pergaulan dengan teman sebaya penting untuk mendorong perkembangan psikososial individu dalam bergaul dan bersosialisasi dengan orang lain. Dengan pergaulan teman sebaya juga dapat membawa dampak positif dan negatif bagi semua orang utamanya pasa usia remaja. Usia remaja merupakan suatu tahapan yang banyak terjadi perubahan baik dalam aspek fisik maupun psikologis, pada saat tersebut mereka diharapkan untuk dapat menyesuaikan diri terhadap perubahan yang dialami maupun efek dari perubahan yang dialaminya. Sehingga perilaku dalam kelompoknya akan sangat berpengaruh terhadap perilaku individu anggotanya. Hal ini seuai dengan hasil penelitian ini bahwa teman sebaya berpengaruh terhadap perilaku konsumtif mahasiswa karena nilai sig. sebesar 0.019 lebih besar dari nilai probabilitas 0.05 . Perilaku konsumtif mahasiswa disebabkan karena mereka telah masuk ke kelompok teman-teman dari berbagai latar belakang baik sosial, ekonomi, keluarga dan sebagainya. Sehingga untuk menunjukkan jatidirinya dikelompoknya mereka cenderung untuk berpenampilan berbeda dengan yang lainnya, sehingga untuk memenuhi keinginnnya mereka akan membelanjakan uangnya untuk mendapatkan penampilan yang diinginkan. Darmiyati (1995) mengatakan bahwa tindakan seseorang selain dipengaruhi keyakinan pribadi (behavior belief) juga di pengaruhi oleh keyakinan kelompok (group belief). Individu akan cenderung melakukan tindakan tertentu jika orang tersebut yakin bahwa tindakannya itu akan disetujui oleh kelompoknya. Sebalik- 
nya tidak akan mendukungnya apabila ia yakin bahwa kelompoknya.

Sesuai dengan hasil pengujian hipotesis 3 terbukti bahwa ada pengaruh media sosial dan pergaulan teman sebaya secara simultan terhadap perilaku konsumtif karena nilai sig. sebesar 0.000 lebih kecil dari nilai probabilitas 0.05. Dengan demikian dapat dikatakan bahwa dengan adanya berbagai tawaran promosi, kemudahan berbelanja, harga yang murah, cepat, praktis dapat membeli berbagai produk yang diinginkan tanpa harus datang ke lokasi penjualan yang ada di media sosial dan pergaulan teman sebaya baik teman kampus maupun teman di duna maya dapat memprediksi atau mempengaruhi perilaku konsumtif mahasiswa. Dengan adanya media sosial dan pergaulan teman sebaya akan mampu merubah pola pikir dan gaya hidup seseorang untuk cenderung konsumtif.

\section{PENUTUP}

\section{Simpulan}

Berdasarkan hasil analisa data simpulannya adalah sebagai berikut: 1) Ada pengaruh media sosial terhadap perilaku konsumtif mahasiswa hal ini ditunjukkan oleh nilai sig 0,006 $\leq 0,05 \mathrm{Ha}$ diterima Ho di tolak. 2) Ada pengaruh pergaulan teman sebaya terhadap perilaku konsumtif mahasiswa hal ini ditunjukkan oleh nilai sig 0,009 $\leq 0,05 \mathrm{Ha}$ di terima Ho ditolak. 3) Ada pengaruh media sosial dan teman sebaya secara bersamaan terhadap perilaku konsumtif mahasiswa hal ini ditunjukkan oleh nilai sig. 0,021 $\leq 0,05$, sehingga Ha diterima Ho di tolak. Dengan demikian dapat dikatakan bahwa variabel media sosial dan teman sebaya baik secara sendiri-sendiri maupun bersamaan dapat mempengaruhi perilaku konsumtif mahasiswa.

\section{Saran}

Adapun beberapa saran yang peneliti berikan dalam penelitian yang telah dilaksanakan antara lain: 1) Untuk penggunaan media sosial, agar lebih bijaksana tidak mengikuti orang lain atau trend yang sedang happening, sehingga setiap individu harus menyadari bahwa apa yang mereka ketahui di media sosial belum tentu baik untuk perkembangan perilakunya.; 2) Dalam pergaulan teman sebaya mahasiswa bisa membawa dampak positif bagi lingkungannya serta saling memotivasi dalam hal kebaikan; 3) Dengan adanya media sosial bisa dimanfaatkan untuk membangun komunitas untuk bersama-sama berkumpul dan menerapkan prinsip ekonomi dan menjauhi perilaku yang cenderung konsumtif.

\section{DAFTAR PUSTAKA}

Ahmadi, Abu.2004. Sosiologi Pendidikan. Jakarta:Rineka Cipta

Azwar. 2009. Sikap Manusia Teori dan Pengukurannya. Edisi ke 2. Yogyakarta: Pustaka Pelajar.

Dariyo, Agoes. 2004. Psikologi Perkembangan Remaja. Jakarta: Ghalia Indonesia

Darmiyati Zuchdi. 1995. "Pembentukan Sikap",Cakrawala Pendidikan. No. 3. Th.XIV, November. Yogyakarta: LPM IKIP Yogyakarta. Hlm. 51-63.

Hidayat, Z. 2014. Masa Depan Media, Masa Depan Indonesia: Perubahan Konsepsi Khalayak ke Partisipan dalam Perspektif Generasi, dalam Masa Depan Komunikasi, Masa Depan Indonesia: Jurnalisme Profesional dan Literasi Media. hlm.41-82. Rajab Ritonga (editor). Jakarta: ISKI Press. 
Haditomo, Siti Rahayu. 2004. Psikologi Perkembangan.Yogyakarta: Gadjah Mada Universty

Mappiare, Andi. 1982. Psikologi Remaja. Surabaya: Usaha Nasional

Suminar dan Meiyuntari. 2013. Konsep Diri, Konformitas dan Perilaku Konsumtif pada Remaja, Personal. Jurnal Psikologi Indonesia. Mei 2015, Vol. 4, No. 02, hal 145 - 152.
Sarwono. 2009. Pengantar Psikologi Umum. Jakarta: Raja Grafindo Persada.

Saifuddin, Azwar. 1997. Metode Penelitian. Yogyakarta: Pustaka Pelajar.

Sentrock, John W. 2007. Perkembangan Anak Jilid 2. Jakarta: Erlangga.

https://id.wikipedia.orang/wiki/facebook

https://id.wikipedia.org/wiki/Internet. 